\title{
Preface: Building social capacities for natural hazards: an emerging field for research and practice in Europe
}

\author{
C. Kuhlicke ${ }^{1}$ and A. Steinführer ${ }^{2}$ \\ ${ }^{1}$ Helmholtz Centre for Environmental Research - UFZ, Department of Urban and Environmental Sociology, \\ Permoserstraße 15, 04318 Leipzig, Germany \\ ${ }^{2}$ Institute of Rural Studies, Johann Heinrich von Thünen Institute, Federal Research Institute for Rural Areas, \\ Forestry and Fisheries, Bundesallee 50, 38116 Braunschweig, Germany \\ Correspondence to: C. Kuhlicke (christian.kuhlicke@ufz.de)
}

Published: 21 October 2015

\section{Introduction}

"Capacities" have gained considerable attention in the field of disaster risk reduction and climate change adaptation; this at least is the impression that one gets when reading through scientific publications published over the past few years. The notion of "capacity" is considered as being integral to the concept of vulnerability, i.e. the function of exposure, susceptibility, coping and/or adaptive capacity (Fuchs et al., 2011); it is fundamental to the idea of resilience and its emphasis on how a system is able to absorb shocks and disturbances (Lorenz, 2013) and also central to the consequences of climate change (IPCC, 2007). But the idea of capacities has also gained prominence on the policy level. The Hyogo Framework for Action 2005-2015 (UN-ISDR, 2005), for instance, promotes local-level disaster reduction and acknowledges that for such a shift to take place, capacity building efforts are required (UN-ISDR, 2005). The Climate and Disaster Resilience Initiative (CDRI) also launched a so-called capacity-building programme in a number of Asian cities in order to enhance the awareness and communication skills of local decision makers with regard to climate-related risks in their cities (CDRI, 2010).

More recently, while the notion of "capacity" is increasingly present, its actual meaning is often taken for granted and, thus, rarely defined. According to the OECD (Organisation for Economic Co-operation and Development) Development Co-operation Directorate (DCD-DAC) (2006), capacity can be generally defined as "the ability of people, organisations and society as a whole to manage their affairs successfully" (Baser and Morgan, 2008, p. 22). A broader search, particularly in development and hazard research, reveals that the term is widely used to encapsulate a broad set of resources (including abilities, skills, financial means, competences, and social relations) of an individual or a social entity (such as a group, a local community or even an entire society) including capacities that are either actually available or provide a potential capacity (i.e. to something latent). Moreover, "capacity" always refers to the existence of something positive. Therefore a lack of capacities implies some sort of deficit. A deficit in capacities thus requires capacity building. Although the explicit term "social capacity building" is only sparsely used, all definitions and approaches basically relate to a social endeavour based on learning, increasing abilities and resources as well as improving interactions between different actors.

This special issue entitled "Building social capacities for natural hazards: an emerging field for research and practice in Europe" offers a forum to different views and conceptualizations dealing with capacities and their development. By doing so, this special issue structures this new and interdisciplinary topic by identifying different types of capacities, different approaches to building and enhancing capacities as well as good practices from across Europe. The single papers come from and reflect a broad range of research domains centring on more established concepts in risk and hazard research such as risk governance, risk perception, social vulnerability, or risk communication. As the single contributions show, in all of these different strands of research and established fields of policy different conceptualizations of social capacities and how to enhance and develop them exist. This special issue intends to identify unifying topics and general 
insights relevant for further developing this field of research and practice.

\section{Background of and motivation to this special issue}

In disaster prevention and risk management, Europe is usually regarded as capacity builder rather than a place where social capacities need to be built. But with economic damages due to natural hazards not decreasing, new prevention strategies need to better address and include a wide range of actors within risk management settings - from people at risk to organizations and authorities in charge. Understanding their perceptions and behaviour is a continuous challenge for successful risk management (Kuhlicke et al., 2012).

Given this background, the European Commission in its 7th Framework Programme funded the research network CapHaz-Net as a so-called coordination action to summarize the state of the art of social-science research on natural hazards by focusing on the topics of social capacity building, risk governance, risk perception, social vulnerability, risk communication and risk education (Kuhlicke et al., 2012). Between 2009 and 2012, the CapHaz-Net project - a consortium of eight research institutes from six countries provided six overview reports and two synthesis reports (all available at http://caphaz-net.org/outcomes-results). It conducted eight workshops with about 170 participants from research and practice. Three of them focused on specific natural hazards (droughts, forest fires, heat waves, Alpine hazards and river floods) in distinct European regional governance settings. Altogether, CapHaz-Net established an intense exchange among a wide range of researchers and practitioners from different European countries.

A typology was developed containing five types of social capacities (Kuhlicke et al., 2012, p. 20).

- Knowledge: this capacity is available in different forms and degrees of codification. Thus, it includes both formal (e.g. written-down) and non-codified (e.g. local) knowledge.

- Motivation: this capacity refers to the general willingness to take notice of and deal with natural hazards. It includes awareness, responsibility and ownership. As a means to establish or trigger risk-related motivations, emotions (e.g. linked to previous disaster experience), incentives (e.g. co-funding for hazard-proof buildings), interests (e.g. because assets are in areas of risk) and trust (e.g. in authorities or other members of community) were identified.

- Social networks: this capacity relates to the possession and exploitation of social capital which describes the "aggregate of the actual or potential resources which are linked to possession of a durable network of more or less institutionalized relationships of mutual acquaintance and recognition" (Bourdieu, 1986, p. 248). Social

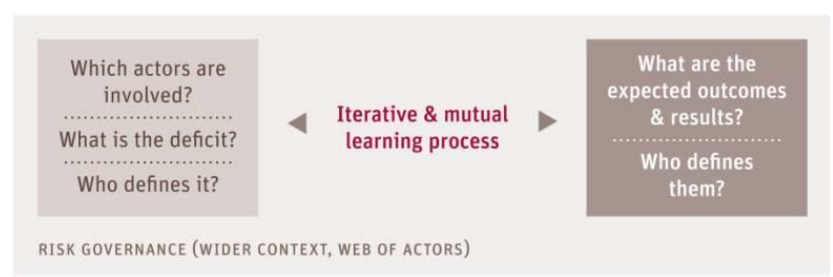

Figure 1. Questions to be answered in the process of social capacity building. Source: authors.

networks are considered to be a key social capacity as they might act as transmitters of all other types of capacities of the typology. Furthermore, they are used in interactions among and between communities and organizations. Yet, social networks should not be romanticized, as they not only contribute to internal cohesion but might also lead to fragmentation.

- Financial resources: this capacity includes incentives, public and private funds as well as insurance policies. There is a strong link to governance capacities as financial resources are often related to issues of distribution, transparency and perceived justice/injustice.

- Governance: this capacity relates to participation opportunities and fair rules for interaction. In a comparative perspective it is evident, that across Europe a highly diversified governance landscape of risk management still exists (e.g. strong vs. weak or paternalist vs. nonpaternalist approaches).

Social capacity building was conceptualized as a long-term, iterative and mutual learning process which is based on the cooperation and interaction of a variety of individual and corporative actors and which is never finished. To steer the process, a number of key questions was formulated (Fig. 1).

Key significance was given to the question of whose capacities need to be improved. A great deal of the research literature focuses on the population at risk, whether that is individuals, private households, social groups or local communities. Yet, social capacity building also has to take into account the organizations and authorities involved in managing natural hazards (e.g. municipal or regional authorities, hazard protection agencies, ministries, etc.). Either of these two distinct groups of actors are increasingly confronted with new challenges and tasks in risk management (e.g. by changing legislative frameworks and an increasing complexity of the management process itself). This creates new roles and responsibilities. Consequently, participation and involvement were thus found to be at the heart of any effort to develop and improve social capacities to prepare for, cope with and recover from the negative impacts of natural hazards. Questions of risk governance are therefore central for social capacity building efforts (Fig. 1). Any such process at its onset requires a transparent assessment of existing social capaci- 
ties as well as a clear definition of the desired outcomes (for more detail see Kuhlicke et al., 2011). In its final report (Kuhlicke et al., 2012), CapHaz-Net suggested respective assessment tools for local communities and risk management organizations. Examples of good practices from different European countries were provided, and recommendations on how to improve social capacity building as well as open research questions were formulated.

\section{Taking social capacity research further: the contributions in this special issue}

The 10 papers of this special issue provide a broad overview of a variety of topics related to social capacity building. In the following, we will shed more light on four overlapping themes.

- Social capacity building should consider problems of social vulnerability in order to better understand the negative impacts of natural hazards and climate change.

- Social capacity building should be embedded in complex risk governance processes at local, regional, national and even international levels.

- Social capacity building should be based upon two-way risk communication processes that take the idea of participation of multiple actors in natural hazard management serious.

- Social capacity building is not restricted to Europe but should also be a global effort that is pursued by international research projects.

\subsection{Social capacities in the context of vulnerability and climate change adaptation research}

In vulnerability and climate adaptation research, the idea of social capacities is conceptualized in a number of varying ways and often referred to as the response, coping or adaptive capacity of individuals, communities, regions or, more generally, systems. In vulnerability research, one of the earliest sustained definitions of vulnerability provided by Chambers (1989) gives a negative definition of capacities by emphasizing the double-sided character of vulnerability: "Vulnerability has thus two sides: an external side of risks, shocks and stress to which an individual or household is subject; and an internal side which is defenselessness, meaning a lack of means to cope with damaging losses" (Chambers, 1989, p. 38). Therefore, social capacities are an integral part of internal vulnerability, referring to individuals, social groups, organizations or communities and their existent and/or nonexistent abilities and resources to come to terms with actual or potential stressing, threatening or damaging events. The external side is then usually understood as the exposure or susceptibility of actors or systems (Fuchs et al., 2011). This basic conceptualization is also reflected in five contributions to the special issue, which we now discuss.

Armaş and Gavriş (2013) use a multi-criteria method for analyzing the social vulnerability of various urban neighbourhoods in order to inform authorities, citizens and decision-makers about the potential risk arising from earthquakes. The paper underlines how the assessment of vulnerability is not only about assessing capacities but that it also may become a starting point for using the results for building awareness and an information base for prospective decision making.

Werg et al. (2013) expand the discussion by going beyond classical vulnerability indicators such as age, income, level of education, and gender. They focus on the role of psychological and governance-related factors and how they shape the vulnerability of individuals and households, at least in the view of experts. The survey reveals that, quite surprisingly, experts evaluate classical vulnerability indicators as more relevant than the proposed psychological ones. The authors do not reject the inclusion of psychological or governance-related factors in vulnerability assessments, but propose a pragmatic, complementary strategy that focuses on a more spatially focused in-depth analysis. This analysis goes beyond exposure and classical socioeconomic-demographic indicators in areas that have been previously identified as hotspots of vulnerability. This might be a useful approach for understanding the local contexts as well as for developing capacities more effectively.

Grothmann et al. (2013) follow a similar line of argument and focus on how to integrate psychological components in the assessment of adaptive capacities of institutions. In their contribution they extend the adaptive capacity wheel by including "adaptation motivation" as well as "adaptation belief" of actors working in such different fields as water management, flood/coastal protection, civil protection and regional planning in their analysis. The authors conclude that an extended view on adaptive capacities is quite fruitful although some methodological challenges still need to be solved.

Kruse and Seidl (2013) also concentrate on the views of commercial water users, policy makers, and decision makers. Their analysis highlights that institutional actors think that while sufficient capacities are in place with regard to reactive crisis management there is still a need for improvement in direction of a proactive strategic drought management. This would require advancement with regard to technologies and infrastructures as well as in a more general sense an integrated view on drought risk management.

Działek et al. (2013) make reference to the framework of social capacity building. They identify profound differences between rural communities and urban areas in their analysis of residents' risk perception and attitudes towards risk management. As a result, they ask for a more comprehensive approach to flood management in Poland that considers the idea of social capacity building. 


\subsection{Social capacities and the idea of risk governance}

Authorities and organizations involved in managing natural hazards as well as residents and local communities exposed to such hazards are increasingly confronted with new challenges and tasks that they need to consider and address. This not only relates to the potentially increasing risks associated with the occurrence of natural hazards due to, among other drivers, the consequences of climate change and ongoing urbanization processes in metropolitan areas. It also relates to changing legislative frameworks (e.g. the European Floods Directive) and an increasing complexity of the management process itself. This creates new roles and responsibilities that communities at risk, as well as organizations involved in the management process, are expected to be able to deal with (Begg et al., 2015).

The transformation of risk management into risk governance has resulted in the need to consider social capacity building at different scales. New particularly non-state actors, including individual citizens and those from the private sector, are joining those with more established hazard management roles in the risk governance process. By adopting a network management perspective Hutter (2014), in this special issue, places the effectiveness of different forms of networking with regard to social capacity building at the heart of his analysis. He shows how the establishment of a network's goal is by no means a process that should be taken for granted. In fact, for effective networking to occur, the effort to make sense of a collective's goal is crucial.

How do governance frameworks between natural hazards but also between countries differ? In order to better understand commonalities and differences between and among distinct governance settings, Walker et al. (2014), also in this special issue, propose a risk profiling framework. Eight key characteristics allow stakeholders to qualitatively evaluate the governance setting of a specific context in order to unravel different views and perspectives and stimulate discussion and exchange on how risks are and should be governed. As demonstrated by means of examples from different European countries, the profile can be applied at different spatial levels (such as country, region or community at risk).

\subsection{Social capacities in the context of risk communication and participation}

The changing landscape of risk governance also requires continuous communication with a multiplicity of actors. Merz et al. (2010, p. 522) state with regard to flood risk management: "The increasingly prominent role of non-structural measures requires a much larger involvement of the public, and a functioning dialogue on the flood risk and mitigation options is an essential element of an integrated flood risk management". Risk communication thus becomes more demanding and more complex. The increasing number and diversity of actors that are perceived to have a legitimate stake or right to be involved in risk management and governance comes with multiplying expectations of how risk communication should be enacted and what it should ideally achieve (Höppner et al., 2010). Risk communication has been enshrined as a fiduciary responsibility of official bodies in a number of European and international policy documents and translated into national law and regulation, though to varying extents across countries (Wright et al., 2006). It is important to note that although guidelines on the communication of technological, chemical, food and health risks have emerged, there is hitherto no generic document that specifically sets out legal requirements or recommendations for the communication of natural hazards at the European level. Moreover, and in spite of some improvements in the past years particularly in flood risk management, most efforts are still realized by one-way communication (such as informing the public) rather than real two-way communication that might improve a sense of ownership by those at risk (Höppner et al., 2010).

In another one of the special issue articles, Buchecker et al. (2013) scrutinize the extent to which participatory forms of interaction between experts, administrations and citizens contribute to enhancing social capacities of residents at risk. Although participation is repeatedly claimed to be relevant for decision making processes, its actual effectiveness or more generally its consequences for building capacities are hardly analyzed in a systematic way. By analyzing six river revitalization projects in Switzerland, Buchecker et al. (2013) triangulate different methodological approaches in order to understand what effects stakeholder involvement has on building social capacities. The authors show that participatory processes contribute to knowledge transfer but may also have the potential to support stakeholders' mutual understanding as well as their sense of ownership, at least when well designed.

Kjellgren (2013) in her special issue contribution focuses on how flood hazard maps are employed for increasing the risk awareness in order to lead to attitudinal and behavioural changes. Based on interviews with decision-makers she identifies obstacles such as unwillingness to cause worry or lack of skills and resources for using maps more effectively for risk communication purposes including by means of true two-way communication.

\subsection{The policy relevance of social capacity building}

Finally, in their special-issue brief communication, Hare et al. (2014) outline some of the key recommendations that emerged out of intensive stakeholder collaboration processes in different regions of the world. The paper also points to the role of cross-national and cross-cultural research as part of social capacity building.

Table 1 provides an overview of the topics, main concepts and the central findings of the 10 papers in this special issue, as well as their implications for social capacity building. 
Table 1. Overview of the single contributions.

\begin{tabular}{|c|c|c|c|c|c|}
\hline & General topic & $\begin{array}{l}\text { Natural } \\
\text { hazard(s) } \\
\text { considered }\end{array}$ & Main concepts & Central findings & $\begin{array}{l}\text { Implications for } \\
\text { social capacity } \\
\text { building }\end{array}$ \\
\hline $\begin{array}{l}\text { Armaş and } \\
\text { Gavriş } \\
(2013)\end{array}$ & $\begin{array}{l}\text { Social } \\
\text { vulnerability } \\
\text { assessments }\end{array}$ & Earthquakes & $\begin{array}{l}\text { Social } \\
\text { vulnerability } \\
\text { index (SoVI } \\
\text { model) and } \\
\text { spatial multi- } \\
\text { criteria social } \\
\text { vulnerability } \\
\text { index (SEVI } \\
\text { model) }\end{array}$ & $\begin{array}{l}\text { Identification of } \\
\text { clustering spots } \\
\text { defined by high } \\
\text { degrees of social } \\
\text { vulnerabilities }\end{array}$ & $\begin{array}{l}\text { Quantitative } \\
\text { vulnerability } \\
\text { assessment } \\
\text { should inform } \\
\text { decision-making } \\
\text { processes on the } \\
\text { city level }\end{array}$ \\
\hline $\begin{array}{l}\text { Buchecker } \\
\text { et al. (2013) }\end{array}$ & $\begin{array}{l}\text { Participation } \\
\text { and social } \\
\text { capacity } \\
\text { building }\end{array}$ & River floods & $\begin{array}{l}\text { Knowledge } \\
\text { capacities, } \\
\text { motivational } \\
\text { capacities, } \\
\text { network } \\
\text { capacities, } \\
\text { acceptance } \\
\text { building }\end{array}$ & $\begin{array}{l}\text { Social learning in } \\
\text { the sense of } \\
\text { change of } \\
\text { attitudes takes } \\
\text { place, improved } \\
\text { collaboration } \\
\text { between } \\
\text { stakeholders, } \\
\text { acceptance } \\
\text { building only of } \\
\text { moderate } \\
\text { relevance, trust } \\
\text { building of } \\
\text { subordinate } \\
\text { relevance }\end{array}$ & $\begin{array}{l}\text { Stakeholder } \\
\text { involvement } \\
\text { should be } \\
\text { designed as a tool } \\
\text { for long-term } \\
\text { social learning } \\
\text { (and not just for } \\
\text { implementing a } \\
\text { project) }\end{array}$ \\
\hline $\begin{array}{l}\text { Działek et } \\
\text { al. (2013) }\end{array}$ & $\begin{array}{l}\text { Social capacity } \\
\text { building in } \\
\text { different socio- } \\
\text { spatial settings }\end{array}$ & River floods & $\begin{array}{l}\text { Knowledge, } \\
\text { motivational, } \\
\text { network, } \\
\text { economic and } \\
\text { governance } \\
\text { capacities }\end{array}$ & $\begin{array}{l}\text { Profound } \\
\text { differences } \\
\text { between rural } \\
\text { communities with } \\
\text { strong networks } \\
\text { and ties, and } \\
\text { larger } \\
\text { communities with } \\
\text { weaker ties were } \\
\text { identified }\end{array}$ & $\begin{array}{l}\text { A more } \\
\text { comprehensive } \\
\text { approach to flood } \\
\text { management is } \\
\text { necessary, } \\
\text { concept of social } \\
\text { capacity building a } \\
\text { useful way of } \\
\text { framing the } \\
\text { challenges }\end{array}$ \\
\hline $\begin{array}{l}\text { Grothmann } \\
\text { et al. (2013) }\end{array}$ & $\begin{array}{l}\text { Institutional } \\
\text { capacity } \\
\text { building }\end{array}$ & $\begin{array}{l}\text { Coastal floods, } \\
\text { climate } \\
\text { change }\end{array}$ & $\begin{array}{l}\text { Psychological } \\
\text { factors } \\
\text { (adaptation } \\
\text { motivation, } \\
\text { adaptation } \\
\text { belief) in climate } \\
\text { change }\end{array}$ & $\begin{array}{l}\text { Adaptive capacity } \\
\text { wheel by Gupta } \\
\text { et al. (2010) was } \\
\text { found to be a } \\
\text { useful heuristic to } \\
\text { assess social } \\
\text { factors in climate } \\
\text { change } \\
\text { adaptation and } \\
\text { developed further }\end{array}$ & $\begin{array}{l}\text { Social capacity } \\
\text { building in the } \\
\text { field of natural } \\
\text { hazards and, more } \\
\text { generally, climate } \\
\text { change } \\
\text { adaptation } \\
\text { governance need } \\
\text { to consider } \\
\text { psychological } \\
\text { factors and } \\
\text { impediments }\end{array}$ \\
\hline
\end{tabular}


Table 1. Continued.

\begin{tabular}{|c|c|c|c|c|c|}
\hline & General topic & $\begin{array}{l}\text { Natural } \\
\text { hazard(s) } \\
\text { considered }\end{array}$ & Main concepts & Central findings & $\begin{array}{l}\text { Implications for } \\
\text { social capacity } \\
\text { building }\end{array}$ \\
\hline $\begin{array}{l}\text { Hare et al. } \\
(2014)\end{array}$ & $\begin{array}{l}\text { Capacity } \\
\text { development in } \\
\text { disaster risk } \\
\text { reduction (DRR) } \\
\text { and climate } \\
\text { change } \\
\text { adaptation } \\
\text { (CCA) }\end{array}$ & $\begin{array}{l}\text { Various hydro- } \\
\text { meteorological } \\
\text { and geological } \\
\text { hazards, } \\
\text { climate } \\
\text { change }\end{array}$ & $\begin{array}{l}\text { Multi-regional } \\
\text { and multi- } \\
\text { stakeholder } \\
\text { think thank } \\
\text { process }\end{array}$ & $\begin{array}{l}\text { It is necessary } \\
\text { to mainstream } \\
\text { DRR and CCA into } \\
\text { policy frameworks, } \\
\text { to taylor capacity } \\
\text { development } \\
\text { activities } \\
\text { to differenct } \\
\text { governance } \\
\text { structures, and } \\
\text { to re-link urban } \\
\text { and rural } \\
\text { communities }\end{array}$ & $\begin{array}{l}\text { Face-to-face } \\
\text { interaction will } \\
\text { furthermore play } \\
\text { a decisive role in } \\
\text { capacity } \\
\text { development }\end{array}$ \\
\hline $\begin{array}{l}\text { Hutter } \\
(2014)\end{array}$ & $\begin{array}{l}\text { Networks and } \\
\text { networking in } \\
\text { risk governance }\end{array}$ & $\begin{array}{l}\text { River floods, } \\
\text { soil erosion, } \\
\text { climate } \\
\text { change }\end{array}$ & $\begin{array}{l}\text { Goal oriented } \\
\text { networks, social } \\
\text { capacity } \\
\text { building, } \\
\text { the process of } \\
\text { sense-making, } \\
\text { network size, } \\
\text { composition of } \\
\text { network actors, } \\
\text { network } \\
\text { governance } \\
\text { form }\end{array}$ & $\begin{array}{l}\text { Large } \\
\text { project networks } \\
\text { may face } \\
\text { difficulties in the } \\
\text { governance of the } \\
\text { project network } \\
\text { governance form }\end{array}$ & $\begin{array}{l}\text { For effective } \\
\text { networking } \\
\text { intensive } \\
\text { collective sense- } \\
\text { making processes } \\
\text { of network's } \\
\text { actual goals are } \\
\text { decisive }\end{array}$ \\
\hline $\begin{array}{l}\text { Kjellgren } \\
(2013)\end{array}$ & $\begin{array}{l}\text { Flood hazard } \\
\text { maps and risk } \\
\text { communication }\end{array}$ & River floods & $\begin{array}{l}\text { Barriers for } \\
\text { using maps as } \\
\text { risk } \\
\text { communication } \\
\text { tools in practice }\end{array}$ & $\begin{array}{l}\text { Identified barriers } \\
\text { for using maps in } \\
\text { practice are } \\
\text { perceived } \\
\text { disinterest among } \\
\text { residents at risk, } \\
\text { unwillingness to } \\
\text { cause } \\
\text { worry or distress, } \\
\text { lack of skills and } \\
\text { resources and } \\
\text { insufficient } \\
\text { support }\end{array}$ & $\begin{array}{l}\text { Barriers need to } \\
\text { be addressed in } \\
\text { order to more } \\
\text { effectively use } \\
\text { maps as risk } \\
\text { communication } \\
\text { tools and hence } \\
\text { contribute to } \\
\text { social capacity } \\
\text { building }\end{array}$ \\
\hline
\end{tabular}


Table 1. Continued.

\begin{tabular}{|c|c|c|c|c|c|}
\hline & General topic & $\begin{array}{l}\text { Natural } \\
\text { hazard(s) } \\
\text { considered }\end{array}$ & Main concepts & Central findings & $\begin{array}{l}\text { Implications for } \\
\text { social capacity } \\
\text { building }\end{array}$ \\
\hline $\begin{array}{l}\text { Kruse and } \\
\text { Seidl (2013) }\end{array}$ & $\begin{array}{l}\text { Social capacity } \\
\text { building as part } \\
\text { of institutional } \\
\text { risk } \\
\text { management }\end{array}$ & Droughts & $\begin{array}{l}\text { Information and } \\
\text { knowledge, } \\
\text { technology and } \\
\text { infrastructure, } \\
\text { organization } \\
\text { and } \\
\text { management, } \\
\text { economic } \\
\text { resource, } \\
\text { institutions and } \\
\text { policies }\end{array}$ & $\begin{array}{l}\text { While sufficient } \\
\text { capacities with } \\
\text { regard to reactive } \\
\text { crisis } \\
\text { management was } \\
\text { stated, capacity } \\
\text { building needed in } \\
\text { proactive } \\
\text { strategic drought } \\
\text { management, } \\
\text { particularly } \\
\text { advancements } \\
\text { with regard to } \\
\text { technologies and } \\
\text { infrastructures } \\
\text { and integrated } \\
\text { drought risk } \\
\text { management } \\
\text { strategies are } \\
\text { missing }\end{array}$ & $\begin{array}{l}\text { Lessons should be } \\
\text { learnt in drought } \\
\text { management } \\
\text { from other } \\
\text { natural hazard risk } \\
\text { management } \\
\text { frameworks; } \\
\text { institutional } \\
\text { fragmentation } \\
\text { should be } \\
\text { overcome by } \\
\text { more consistent } \\
\text { regulations and } \\
\text { coordination }\end{array}$ \\
\hline $\begin{array}{l}\text { Walker et } \\
\text { al. (2014) }\end{array}$ & $\begin{array}{l}\text { Risk } \\
\text { governance in a } \\
\text { cross-European } \\
\text { approach }\end{array}$ & $\begin{array}{l}\text { Earthquakes, } \\
\text { volcanic } \\
\text { eruptions, } \\
\text { landslides, } \\
\text { river floods }\end{array}$ & $\begin{array}{l}\text { Risk governance } \\
\text { profiling } \\
\text { framework } \\
\text { constituted by } \\
\text { eight different } \\
\text { governance } \\
\text { characteristics }\end{array}$ & $\begin{array}{l}\text { Framework } \\
\text { intended to } \\
\text { represent and } \\
\text { evaluate key } \\
\text { characteristics of } \\
\text { how natural } \\
\text { hazards are } \\
\text { governed and how this } \\
\text { process is shaped } \\
\text { by different forms } \\
\text { of hazard and } \\
\text { political contexts }\end{array}$ & $\begin{array}{l}\text { Framework may } \\
\text { be used to unravel } \\
\text { diverging views } \\
\text { among different } \\
\text { stakeholder } \\
\text { groups on specific } \\
\text { governance } \\
\text { setting or on how } \\
\text { within a specific } \\
\text { setting a } \\
\text { governance } \\
\text { framework should } \\
\text { change }\end{array}$ \\
\hline $\begin{array}{l}\text { Werg et al. } \\
(2013)\end{array}$ & $\begin{array}{l}\text { Social } \\
\text { vulnerability } \\
\text { and social } \\
\text { capacity } \\
\text { assessments }\end{array}$ & $\begin{array}{l}\text { Various hydro- } \\
\text { meteorological } \\
\text { and geological } \\
\text { hazards, } \\
\text { climate } \\
\text { change }\end{array}$ & $\begin{array}{l}\text { Psychological } \\
\text { factors (e.g. } \\
\text { cognition, } \\
\text { emotions, } \\
\text { experience) and } \\
\text { governance } \\
\text { factors (e.g. } \\
\text { existence of } \\
\text { emergency } \\
\text { plans, } \\
\text { participation) }\end{array}$ & $\begin{array}{l}\text { Traditional } \\
\text { vulnerability } \\
\text { indicators such as } \\
\text { age, income, and } \\
\text { gender are ranked } \\
\text { as more relevant } \\
\text { than the } \\
\text { proposed } \\
\text { psychological } \\
\text { ones }\end{array}$ & $\begin{array}{l}\text { Psychological and } \\
\text { governance- } \\
\text { related indicators } \\
\text { should play a } \\
\text { greater role in } \\
\text { vulnerability } \\
\text { assessment in } \\
\text { order to better } \\
\text { understand and } \\
\text { build social } \\
\text { capacities }\end{array}$ \\
\hline
\end{tabular}




\section{Summary and ways forward}

Though not always referred to as such, social capacity building is a topical issue in natural hazards research. Changing modes of risk governance combined with strong expectations concerning an involvement of a variety of actors and both horizontal and vertical integration of different risk management agencies lead to considerable confusion about responsibilities and rights, opportunities and limits of participation in the different phases of risk management. New nonstate actors, including individual citizens and those from the private sector, are joining those with more established hazard management roles in the risk governance process. Although this process is not taking place evenly across Europe (Merz et al., 2010; Walker et al., 2010), it changes the landscape within which research is conducted, practices tested and strategies developed in order to mitigate the negative impacts of risks to an extent that should become an object of research itself. Moreover, reducing social vulnerabilities to the negative impacts of natural hazards and climate change requires a thorough understanding of the different resources, assets and abilities both residents at risk and organizations in charge of risk management dispose of and lack, respectively. CapHaz-Net proposed a certain typology of such social capacities which needs further application and refinement. Several contributions of this special issue adapt and refine this typology or suggest another one. Thus, we understand this collection of papers as a step forward in the research on social capacities and their role in natural hazard mitigation and adaptation.

\section{References}

Armaş, I. and Gavriş, A.: Social vulnerability assessment using spatial multi-criteria analysis (SEVI model) and the Social Vulnerability Index (SoVI model) - a case study for Bucharest, Romania, Nat. Hazards Earth Syst. Sci., 13, 14811499, doi:10.5194/nhess-13-1481-2013, 2013.

Baser, H. and Morgan, P.: Capacity, Change and Performance, Study Report, Discussion Paper No. 59B, ECDPM Discussion Paper 59B, European Centre for Development Policy Management, Maastricht, 2008.

Begg, C., Walker, G., and Kuhlicke, C.: Localism and flood risk management in England: the creation of new inequalities? Environment and Planning C: Government and Policy, http://www. envplan.com/abstract.cgi id=c12216, last access: 25 September 2015, in press, 2015.

Bourdieu, P.: The Forms of Capital, in: Handbook of Theory and Research for the Sociology of Education, edited by: Richardson, J. G., Greenwood Press, New York, 241-258, 1986.

Buchecker, M., Menzel, S., and Home, R.: How much does participatory flood management contribute to stakeholders' social capacity building? Empirical findings based on a triangulation of three evaluation approaches, Nat. Hazards Earth Syst. Sci., 13, 1427-1444, doi:10.5194/nhess-13-1427-2013, 2013.
CDRI - Climate and Disaster Resilience Initiative: Capacitybuilding programme, http://www.unisdr.org/we/inform/ publications/16723 (last access: 29 September 2015), 2010.

Chambers, R.: Editorial introduction: vulnerability, coping and policy, IDS Bulletin, 20, 1-7, 1989.

Działek, J., Biernacki, W., and Bokwa, A.: Challenges to social capacity building in flood-affected areas of southern Poland, Nat. Hazards Earth Syst. Sci., 13, 2555-2566, doi:10.5194/nhess-132555-2013, 2013.

Fuchs, S., Kuhlicke, C., and Meyer, V.: Editorial for the special issue: vulnerability to natural hazards - the challenge of integration, Nat. Hazards, 58, 609-619, 2011.

Grothmann, T., Grecksch, K., Winges, M., and Siebenhüner, B.: Assessing institutional capacities to adapt to climate change: integrating psychological dimensions in the Adaptive Capacity Wheel, Nat. Hazards Earth Syst. Sci., 13, 3369-3384, doi:10.5194/nhess-13-3369-2013, 2013.

Gupta, J., Termeer, K., Klostermann, J., Meijerink, S., van den Brink, M., Jong, P., Nooteboom, S., and Bergsmaa, E.: The Adaptive Capacity Wheel: a method to assess the inherent characteristics of institutions to enable the adaptive capacity of society, Environ. Sci. Policy, 13, 459-471, 2010.

Hare, M. P., van Bers, C., van der Keur, P., Henriksen, H. J., Luther, J., Kuhlicke, C., Jaspers, F., Terwisscha van Scheltinga, C., Mysiak, J., Calliari, E., Warner, K., Daniel, H., Coppola, J., and McGrath, P. F.: Brief Communication: CATALYST - a multi-regional stakeholder think tank for fostering capacity development in disaster risk reduction and climate change adaptation, Nat. Hazards Earth Syst. Sci., 14, 2157-2163, doi:10.5194/nhess-14-2157-2014, 2014.

Höppner, C., Buchecker, M., and Bründl, M.: Risk Communication and Natural Hazards, CapHaz-Net WP5 Report, Swiss Federal Institute for Forest, Snow and Landscape Research WSL and WSL Institute for Snow and Avalanche Research SLF, Birmensdorf and Davos, http://caphaz-net.org/outcomes-results/ CapHaz-Net_WP5Risk-Communication2.pdf (last access: 18 September 2014), 2010.

Hutter, G.: Goal-oriented networks and capacity building for natural hazards - examples in the Dresden region, Nat. Hazards Earth Syst. Sci., 14, 81-94, doi:10.5194/nhess-14-81-2014, 2014.

IPCC: Climate Change 2007, Working Group II, Impacts, Adaptation and Vulnerability, Glossary, http://www.ipcc.ch/ publicationsand_data/ar4/wg2/en/annexessglossary-a-d.html (last access: 18 September 2014), 2007.

Kjellgren, S.: Exploring local risk managers' use of flood hazard maps for risk communication purposes in BadenWürttemberg, Nat. Hazards Earth Syst. Sci., 13, 1857-1872, doi:10.5194/nhess-13-1857-2013, 2013.

Kruse, S. and Seidl, I.: Social capacities for drought risk management in Switzerland, Nat. Hazards Earth Syst. Sci., 13, 34293441, doi:10.5194/nhess-13-3429-2013, 2013.

Kuhlicke, C., Steinführer, A., Begg, C., Bianchizza, C., Bründl, M., Buchecker, M., De Marchi, B., Di Masso Tarditti, M., Höppner, C., Komac, B., Lemkow, L., Luther, J., McCarthy, S., Pellizzoni, L., Renn, O., Scolobig, A., Supramaniam, M., Tapsell, S., Wachinger, G., Walker, G., Whittle, R., and Zorn, M.: Perspectives on social capacity building for natural hazards: Outlining an emerging field of research and practice in Europe, Environ. Sci. Policy, 14, 804-814, 2011. 
Kuhlicke, C., Steinführer, A., Begg, C., and Luther, J.: Toward More Resilient Societies in the Field of Natural Hazards: CapHaz-Net's Lessons Learnt, Final CapHaz-Net Report, Helmholtz Centre for Environmental Research - UFZ, Leipzig, Johann Heinrich von Thünen Institute, Braunschweig, http:// caphaz-net.org/outcomes-results/CapHazNet_Del_10.3final.pdf (last access: 18 September 2014), 2012.

Lorenz, D.: The diversity of resilience: contributions from a social science perspective, Nat. Hazards, 67, 7-24, 2013.

Merz, B., Hall, J., Disse, M., and Schumann, A.: Fluvial flood risk management in a changing world, Nat. Hazards Earth Syst. Sci., 10, 509-527, doi:10.5194/nhess-10-509-2010, 2010.

UN-ISDR: Hyogo framework for action 2005-2015: building the resilience of nations and communities to disasters, http://www. unisdr.org/files/1037_hyogoframeworkforactionenglish.pdf (last access: 21 September 2015), 2005

Walker, G., Whittle, R., Medd, W., and Watson, N.: Risk Governance and Natural Hazards, CapHaz-Net WP2 Report, Lancaster Environment Centre, Lancaster University, Lancaster, http://caphaz-net.org/outcomes-results/CapHaz-Net_ WP2Risk-Governance2.pdf (last access: 18 September 2014), 2010 .
Walker, G., Tweed, F., and Whittle, R.: A framework for profiling the characteristics of risk governance in natural hazard contexts, Nat. Hazards Earth Syst. Sci., 14, 155-164, doi:10.5194/nhess14-155-2014, 2014

Werg, J., Grothmann, T., and Schmidt, P.: Assessing social capacity and vulnerability of private households to natural hazards - integrating psychological and governance factors, Nat. Hazards Earth Syst. Sci., 13, 1613-1628, doi:10.5194/nhess-131613-2013, 2013.

Wright, D., Dressel, K., and Merad, M.: STAkeholders in Risk Communication (STARC) - Risk communication practices in EU Member States, selected other countries and industries, STARC Deliverable 2, London, 2006. 